\title{
Physico-chemical traits of Cajanus cajan (L.) Millsp. pod wall affecting Melanagromyza obtusa (Malloch) damage
}

\author{
R. K. Moudgal $\cdot$ R. K. Lakra $\cdot$ B. Dahiya $\cdot$ \\ M. K. Dhillon
}

Received: 12 January 2007 / Accepted: 11 October 2007 / Published online: 30 October 2007

(C) Springer Science+Business Media B.V. 2007

\begin{abstract}
Pigeonpea [Cajanus cajan (L.) Millsp.] is an important legume crop in the semi-arid tropics, and pod fly [Melanagromyza obtusa (Malloch)] is an important emerging constraint to increase the production and productivity of this crop under subsistence farming conditions. Host plant resistance can be used as an important tool for the management of this pest. Therefore, a set of ten pigeonpea genotypes from a diverse array of plant growth types and maturity groups including two appropriate commercial checks, was evaluated for resistance to pod fly under field conditions, and characterized for physico-chemical pod traits. The non-determinate type GP 75 (extra early maturing) and GP 118 (early maturing), and determinate type GP 233 (extra early maturing) and GP 253 (early maturing) genotypes had significantly lower pod and seed damage as compared to determinate (Prabhat) and non-determinate (Manak) early maturing checks, suggesting that resistance to pod fly is not linked to plant growth type and maturity period
\end{abstract}

R. K. Moudgal $(\bowtie) \cdot$ R. K. Lakra · B. Dahiya

Department of Entomology, Chaudhary Charan Singh

Haryana Agricultural University, Hisar,

Haryana 125 004, India

e-mail: rishikant76@rediffmail.com

M. K. Dhillon

International Crops Research Institute for the Semi-Arid Tropics (ICRISAT), Patnacheru, Andhra Pradesh 502 324, India of the genotype in pigeonpea. Pod wall thickness, trichome density, reducing and non-reducing sugars, total phenols, tannins, and crude fiber were found to be negatively associated ( $r=-0.83 * *$ to $-0.97 * *)$, while total protein positively associated $(r=0.88 * *$ to $0.97 * *)$ with pod fly infestation. Therefore, these traits particularly total phenols, tannins, crude fiber, trichome density, and pod wall thickness, can be used as physico-chemical markers to identify pigeonpea genotypes with resistance to $M$. obtusa, and use in pod fly resistant breeding program in pigeonpea.

Keywords Melanagromyza obtusa $\cdot$ Biochemical traits $\cdot$ Morphological traits $\cdot$ Pigeonpea $\cdot$ Pod wall

\section{Introduction}

Pigeonpea [Cajanus cajan (L.) Millsp.] is one of the major grain legumes in the semi-arid tropics (SAT) (Nene and Sheila 1990). It provides a significant proportion of the daily protein requirements of people living in the SAT. It is grown in over 50 countries in Asia, East and southern Africa, and the Caribbean for food, fodder, fuel wood, rearing lac insects, hedges, windbreaks, soil conservation, green manuring, and roofing (Sharma et al. 2003). Yields of pigeonpea in the farmer's fields have become stagnant for the past four decades, largely because of insect pest damage. More than 200 insect species have been reported to feed on pigeonpea from germination to harvest, of 
which pod fly, Melanagromyza obtusa (Malloch) (Agromyzidae: Diptera) is one of the most important yield reducing factors (Shanower et al. 1998, 1999). It causes an average of $34.5 \%$ pod damage, which in turn results in $29.8 \%$ grain loss (Srivastava 1972). The losses due to pod fly damage have been estimated to be US\$ 256 million annually (ICRISAT 1992).

The maggots of pod fly, M. obtusa damage the maturing grains, thus damaged grains are unfit for human consumption due to development of moulds. The attack of pod fly remains unnoticed by the farmers owing to the concealed mode of life within the pods and thus, become difficult to control. Identification and utilization of pod fly resistant cultivars would provide an equitable and environmentally sound tool for the sustainable management of this difficult to control pest. Earlier studies on pod fly damage have shown that early maturing genotypes suffer more damage than the late maturing ones (Bhosale and Nawale 1985; Lal et al. 1988), and the determinate types are less susceptible than the indeterminate types (Lal et al. 1986; Gupta et al. 1991). More than 10, 000 germplasm accessions have been screened for pod fly resistance (Lateef and Pimbert 1990). Although, several studies have been reviewed on evaluation of different maturity group pigeonpea genotypes for resistance to M. obtusa (Shanower et al. 1998), no definite conclusions could be drawn about the relative susceptibility of pigeonpea genotypes to pod fly damage because of unstaggered flowering and variation in pod fly abundance over time (Reed and Lateef 1990; Singh and Singh 1990). Also very little is known about the bases and mechanisms of resistance to pod fly in pigeonpea. Therefore, the present studies were conducted to identify the pod fly resistant pigeonpea genotypes, and the physico-chemical traits associated with resistance/susceptibility to pod fly from a diverse array of genotypes.

\section{Materials and methods}

\section{Plant material}

The experimental material consisted of eight pod fly resistant and susceptible pigeonpea genotypes (two each from extra-early maturing non-determinate, extra-early maturing determinate, early maturing nondeterminate, and early maturing determinate groups), and two commercial checks, Manak (early maturing and non-determinate plant type) and Prabhat (early maturing and determinate plant type). The test material was selected from the evaluation of 260 pigeonpea accessions for resistance to pod fly during the 2001 cropping season. The experimental material was sown in the research farm at the CCS Haryana Agricultural University, Hisar, India on 13 and 15 June during the 2001 and 2002 cropping seasons, respectively. There were three replications in a randomized complete block design. Each genotype was planted in four row plots, $4 \mathrm{~m}$ long. The plants were thinned to a plant-to-plant spacing of $15 \mathrm{~cm}$, at 15 days after seedling emergence. Normal agronomic practices were followed for raising the crop. No insecticide was applied in the experimental plots.

\section{Evaluation for Melanagromyza obtusa damage}

The mature pods from five randomly selected plants of each test genotype per replication were collected at harvest from all the three replications to estimate the pod and seed damage by M. obtusa during the 2001 and 2002 cropping seasons. Total number of pods and seeds, and pod fly damaged pods and seeds were counted separately, and the data was expressed as percent pod and seed damage.

Influence of physico-chemical traits of pigeonpea pods on Melanagromyza obtusa incidence

To identify the componential traits associated with resistance to pod fly damage, a number of morphological (pod shape, pod length, pod width, pod wall thickness, and trichome density), and biochemical (total protein, reducing sugars, non-reducing sugars, total phenols, tannins, and crude fiber) pod traits were studied under laboratory conditions. A total of 30 green pods of uniform age (30 days after opening of the flowers) from each test genotype were collected from the field for each morphological and biochemical traits from three replications (10 pods/replication). The pod walls of these test pods were retained for physico-chemical estimations, and the seeds were discarded.

Pod length and width were measured in centimeters with the help of digital Vernier Calipers, while pod shape was observed visually. For the measurement of pod wall thickness, the test samples were 
collected in stoppered glass vials (10 ml capacity) containing Formalin-Acetic acid-Alcohol (FAA) solution (Ethanol $50 \mathrm{ml}$; Glacial acetic acid $5 \mathrm{ml}$; Formalin $10 \mathrm{ml} ; \mathrm{H}_{2} \mathrm{O} 35 \mathrm{ml}$ ). After $24-48 \mathrm{~h}$ of storage in FAA solution, the test samples were washed and preserved in $70 \%$ alcohol until further use. At the time of observations on pod wall thickness, the preserved pods were washed in normal tap water and transverse hand sections were cut with the help of a blade. These sections were placed on a slide and pod wall thickness was measured under a microscope fitted with a calibrated ocular micrometer. For the observations on trichome density, the pod skin was peeled off and stained in safranin. The samples were then mounted on a slide with a drop of lactic acid and covered with a cover slip, and observed under the stereomicroscope at $80 \times$ magnification for trichome density. The total number of trichomes (glandular and non-glandular) in the $80 \times$ microscopic field were counted, and then calculated per unit area $\left(\mathrm{mm}^{-2}\right)$.

The uniform age green pods ( 30 days after opening of the flowers) were collected from each entry to obtain the pod wall for biochemical estimations. The pod walls were oven dried at $60^{\circ} \mathrm{C}$ for $2-3$ days. After drying, the test samples were grinded in an electro grinder. The grounded samples were then kept in a paper envelope in oven at $50^{\circ} \mathrm{C}$ for 1 day to ensure complete drying of the samples. The completely dry samples were then used for the estimation of biochemical constituents. Total soluble sugars were estimated using the method of Dubois et al. (1956) and reducing sugars by the method of Snell and Snell (1954), and the data was expressed in percentage. The non-reducing sugars were calculated by subtracting reducing sugars from total soluble sugars (non-reducing sugars $=$ total soluble sugars (reducing sugars) . Total phenols were estimated by following the method given by Swain and Hills (1959) and tannins by the method of Burns (1971), and the data was converted to milligram per gram of dry weight. Protein and crude fiber were estimated by following the standard A.O.A.C. (1995) protocols, and the data was expressed in percentage.

\section{Statistical analysis}

Data was subjected to analysis of variance using GENSTAT, 8.8 Version statistical package. The significance of differences between the genotypes was tested by $F$-test, while the treatment means were compared by least significant difference (LSD) at $P=0.05$. Correlation coefficients between pod fly damage and physico-chemical traits were also analyzed to judge their association with resistance/susceptibility to pod fly.

\section{Results}

Evaluation for Melanagromyza obtusa damage

There were significant differences in pod $(P \leq 0.001$, $d f=9,18 ; F=39.87)$ and grain $(P \leq 0.001, d f=9,18$; $F=24.23$ ) damage by pod fly in different plant type and maturity group pigeonpea genotypes under natural infestation conditions in the field (Table 1). The pod damage by $M$. obtusa ranged between 3.8 and $21.4 \%$ as compared to 13.7 and $18.7 \%$ on commercial checks, Manak and Prabhat, respectively. Grain damage by pod fly maggots varied between 1.6 and $10.3 \%$ on test genotypes as compared to 5.4 and $5.6 \%$ on commercial checks, Manak and Prabhat, respectively. Non-determinate extra early maturing genotype GP 75 , non-determinate early maturing genotype GP 118 , determinate extra early maturing genotype GP 233, and determinate early maturing genotype GP 253 had significantly lower pod and seed damage as compared to determinate (Prabhat) and non-determinate (Manak) early maturing commercial checks, suggesting that the resistance to pod fly is not linked to the growth type and maturity period of the genotype.

Physico-chemical traits of pods of different growth type pigeonpea genotypes

The pod shape was almost straight across test genotypes. Although, there were significant differences for pod length $(P=0.046, d f=9,18 ; F=2.51)$ and pod width $(P=0.026, d f=9,18 ; F=2.90)$ among the test genotypes across maturity groups and plant types, the differences for pod length and pod width among the same plant type test genotypes with their commercial checks were non-significant (Table 1). The pod wall thickness of the pigeonpea test genotypes varied significantly $(P=0.002, d f=9,18 ; F=5.10)$ across maturity groups and plant types. Pod wall thickness of the pod fly resistant pigeonpea genotypes GP 75, GP 118, GP 233, and GP 253 was significantly more 
Table 1 Morphological traits of pods of different pigeonpea genotypes and their reaction to pod fly, Melanagromyza obtusa infestation
${ }^{a}$ Values are means of two cropping seasons

\begin{tabular}{|c|c|c|c|c|c|c|c|}
\hline \multirow[t]{2}{*}{ Genotypes } & \multirow[t]{2}{*}{$\begin{array}{l}\text { Pod } \\
\text { length } \\
(\mathrm{cm})\end{array}$} & \multirow[t]{2}{*}{$\begin{array}{l}\text { Pod } \\
\text { width } \\
(\mathrm{cm})\end{array}$} & \multirow[t]{2}{*}{$\begin{array}{l}\text { Pod wall } \\
\text { thickness } \\
(\mathrm{mm})\end{array}$} & $\begin{array}{l}\text { Trichome } \\
\text { (No. of tric }\end{array}$ & $\begin{array}{l}\text { density } \\
\text { homes } / \mathrm{mm}^{2} \text { ) }\end{array}$ & \multirow[t]{2}{*}{$\begin{array}{l}\text { Pod } \\
\text { damage } \\
(\%)^{\mathrm{a}}\end{array}$} & \multirow[t]{2}{*}{$\begin{array}{l}\text { Grain } \\
\text { damage } \\
(\%)^{\mathrm{a}}\end{array}$} \\
\hline & & & & Glandular & Non-glandular & & \\
\hline
\end{tabular}

Non-determinate type extra early maturing (110 days)

$\begin{array}{lrrrrrrr}\text { GP 75 } & 4.57 & 0.54 & 0.38 & 4.35 & 28.74 & 4.5 & 1.6 \\ \text { GP 25 } & 4.19 & 0.63 & 0.32 & 2.29 & 19.47 & 19.4 & 9.4\end{array}$

Non-determinate type early maturing (130 days)

$\begin{array}{lrrrrrrr}\text { GP 118 } & 4.28 & 0.63 & 0.38 & 4.40 & 27.60 & 5.2 & 2.1 \\ \text { GP 183 } & 5.07 & 0.58 & 0.31 & 2.15 & 19.97 & 21.4 & 10.3 \\ \text { Manak (check) } & 4.44 & 0.58 & 0.35 & 3.94 & 25.25 & 13.7 & 5.6\end{array}$

Determinate type extra early maturing (110 days)

$\begin{array}{llllllrr}\text { GP } 233 & 3.87 & 0.53 & 0.43 & 5.18 & 31.36 & 3.8 & 2.3 \\ \text { GP 242 } & 4.56 & 0.62 & 0.35 & 3.39 & 20.16 & 18.6 & 7.4\end{array}$

Determinate type early maturing (130 days)

\begin{tabular}{cccccccc} 
GP 253 & 4.92 & 0.60 & 0.41 & 4.68 & 30.53 & 4.1 & 2.2 \\
GP 248 & 4.63 & 0.55 & 0.34 & 3.53 & 20.02 & 18.9 & 9.2 \\
Prabhat (check) & 4.42 & 0.58 & 0.36 & 3.99 & 25.11 & 12.7 & 5.4 \\
LSD $(P=0.05)$ & 0.65 & 0.06 & 0.05 & 0.33 & 3.80 & 3.40 & 2.05 \\
\hline
\end{tabular}

than the susceptible ones in the same plant type and maturity group genotypes (Table 1). However, there were no significant differences between non-determinate pigeonpea genotypes with the same plant type commercial check, Manak, and that of determinate type genotypes with the same plant type check, Prabhat (except GP 233, which had significantly more pod wall thickness than the commercial check, Prabhat) for pod wall thickness. There were significant differences among the test pigeonpea genotypes for glandular $(P \leq 0.001, d f=9,18 ; F=77.17)$ and nonglandular $(P \leq 0.001, d f=9,18 ; F=13.30)$ trichomes across maturity groups and plant types. The density of non-glandular trichomes was higher than the glandular trichomes across the test genotypes. The pods of pod fly resistant genotypes (GP 75, GP 118, GP 233, and GP 253) had significantly more number of glandular and non-glandular trichomes than the susceptible genotypes (GP 25, GP 183, GP 242, and GP 248), and the commercial checks across plant types and maturity groups, suggesting that trichome density is associated with resistance to M. obtusa in pigeonpea (Table 1). However, there were no significant differences among the pod fly resistant or susceptible groups of genotypes across plant type and maturity groups for either of the trichome types. The commercial checks had intermediate numbers of glandular and non-glandular trichomes to pod fly resistant and susceptible test genotypes.

There were significant differences in protein $(P=0.006, d f=9,18 ; F=3.95)$, reducing sugars $(P \leq 0.001, d f=9,18 ; F=5.59)$, non-reducing sugars $(P \leq 0.001, d f=9, \quad 18 ; \quad F=51.96)$, total phenols $(P \leq 0.001, \quad d f=9, \quad 18 ; \quad F=76.30), \quad$ tannins $(P \leq 0.001, d f=9,18 ; F=47.50)$, and crude fiber content $(P \leq 0.001, d f=9,18 ; F=17.20)$ of pod walls of different pigeonpea test genotypes. The pod walls of M. obtusa susceptible genotypes had significantly more soluble proteins (14.00-14.58\%) than the resistant group of genotypes (10.21-11.08\%) across plant type and maturity groups (Table 2). Protein content in pod walls of commercial checks, Manak and Prabhat was intermediate to the resistant and susceptible groups of test genotypes, although the differences between commercial checks and the test genotypes were statistically non-significant. The reducing sugars in pod walls of pod fly susceptible genotypes were significantly higher than the resistant group of genotypes across plant type and maturity groups (Table 2). However, reverse was the trend for non-reducing sugars. The total phenols in the pod walls of pod fly resistant pigeonpea genotypes were significantly more $(25.19-25.66 \mathrm{mg} / \mathrm{g})$ than that in susceptible group of genotypes (14.41-14.68 mg/g) and the commercial 
Table 2 Biochemical traits of pods of different pigeonpea genotypes

\begin{tabular}{lllllll}
\hline Genotypes & Protein & Reducing & Non-reducing & Total \\
sugars $(\%)$ & $\begin{array}{l}\text { phenols } \\
(\mathrm{mg} / \mathrm{g})\end{array}$ & $\begin{array}{l}\text { Tannins } \\
(\mathrm{mg} / \mathrm{g})\end{array}$ & $\begin{array}{l}\text { Crude } \\
\text { fiber (\%) }\end{array}$ \\
\hline
\end{tabular}

Non-determinate type extra early maturing (110 days)

$\begin{array}{lllllll}\text { GP 75 } & 11.08 & 1.07 & 3.60 & 25.63 & 4.45 & 54.62 \\ \text { GP 25 } & 14.58 & 1.35 & 2.31 & 14.45 & 2.55 & 52.21\end{array}$

Non-determinate type early maturing (130 days)

$\begin{array}{lllllll}\text { GP } 118 & 10.79 & 1.07 & 3.60 & 25.15 & 4.33 & 54.46 \\ \text { GP } 183 & 14.58 & 1.38 & 1.74 & 14.41 & 2.51 & 52.08 \\ \text { Manak (check) } & 12.83 & 1.18 & 2.91 & 18.48 & 3.35 & 53.88\end{array}$

Determinate type extra early maturing (110 days)

$\begin{array}{lllllll}\text { GP } 233 & 10.21 & 0.94 & 3.80 & 25.66 & 4.50 & 54.57 \\ \text { GP 242 } & 14.00 & 1.32 & 2.40 & 14.68 & 2.61 & 52.28\end{array}$

Determinate type early maturing (130 days)

\begin{tabular}{crrlrrr} 
GP 253 & 10.79 & 0.97 & $3.74(11.15)$ & 25.19 & 4.47 & 54.44 \\
GP 248 & 14.29 & 1.31 & 2.33 & 14.56 & 2.58 & 52.22 \\
Prabhat (check) & 12.54 & 1.19 & 2.90 & 18.33 & 3.39 & 53.81 \\
LSD $(P=0.05)$ & 2.60 & 0.20 & 0.30 & 1.76 & 0.38 & 0.80 \\
\hline
\end{tabular}

checks, suggesting that higher phenol content in pod walls is associated with resistance to M. obtusa in pigeonpea (Table 2). The pod walls of pod fly resistant pigeonpea genotypes had significantly more tannin content $(4.33-4.50 \mathrm{mg} / \mathrm{g})$ as compared to the susceptible group of genotypes $(2.51-2.61 \mathrm{mg} / \mathrm{g}$ ), and the commercial checks, however the differences among the pod fly resistant or susceptible group of genotypes across plant type and maturity groups were non-significant (Table 2). The pod walls of pod fly resistant pigeonpea genotypes were significantly more fibrous $(54.44-54.62 \mathrm{mg} / \mathrm{g}$ ) than the susceptible genotypes $(52.08-52.28 \mathrm{mg} / \mathrm{g})$ across plant type and maturity groups (Table 2 ). There were no significant differences for fiber content in the pod walls of commercial checks, Manak and Prabhat, and that of the resistant group of pigeonpea genotypes.

\section{Association of physico-chemical traits of pigeonpea} pods with resistance to Melanagromyza obtusa

The correlation coefficients between pod or grain damage and physico-chemical pod traits-pod wall thickness, trichome density, reducing (except with grain damage) and non-reducing sugars, total phenols, tannins, and fiber content were significant and negative at $P=0.01$ (Table 3), suggesting that these traits have negative association with pod and grain damage by $M$. obtusa. However, protein content in the pod walls of pigeonpea genotypes is significantly and positively associated with susceptibility to pod fly, M. obtusa damage.

\section{Discussion}

Plant-herbivore interactions are influenced by several physico-chemical plant traits, environmental conditions, and physiological status of the test insects

Table 3 Association of physico-chemical traits of pigeonpea pods with pod fly, Melanagromyza obtusa infestation

\begin{tabular}{lcc}
\hline Physico-chemical traits & Pod damage & Grain damage \\
\hline Pod length & 0.27 & 0.31 \\
Pod width & 0.43 & 0.21 \\
Pod wall thickness & $-0.87 * *$ & $-0.87 * *$ \\
Glandular trichomes & $-0.90^{* *}$ & $-0.89 * *$ \\
Non-glandular trichomes & $-0.85^{* *}$ & $-0.94 * *$ \\
Protein & $0.88^{* *}$ & $0.97 * *$ \\
Reducing sugars & $-0.89 * *$ & $0.93 * *$ \\
Non-reducing sugars & $-0.90^{* *}$ & $-0.97 * *$ \\
Total phenols & $-0.88^{* *}$ & $-0.97 * *$ \\
Tannins & $-0.88^{* *}$ & $-0.97 * *$ \\
Crude fiber & $-0.83^{* *}$ & $-0.97 * *$ \\
\hline
\end{tabular}

**Correlation coefficients significant at $P=0.01$ 
(De Ponti 1977). Morphological characters of plants interfere with oviposition and feeding by the insects, while biochemical constituents confers antibiosis as well as antixenosis mechanisms of resistance to insects. Pigeonpea genotypes GP 75, GP 118, GP 233, and GP 253 representing different plant types and maturity groups were found to be resistant to $M$. obtusa, suggesting that resistance to pod fly is not linked to growth type and maturity period of the genotype. The wild accessions of pigeonpea ICPW 141, ICPW 278, and ICPW 280 (C. scarabaeoides), ICPW 214 ( $C$. bracteata), ICPW 14 ( $C$. albicans), and ICPW 202 (F. stricta) have also been reported to have resistance to pod fly (Sharma et al. 2003). Shanower et al. (1998) have reviewed a number of componential traits associated with resistance to pod fly in pigeonpea. Pod length and width has positive association with pod fly infestation (Veda et al. 1975; ICRISAT 1983; Thakur et al. 1989). Present studies also revealed the similar type of association of pod length and width with pod fly damage, but the correlation coefficients were non-significant. Pod wall thickness is negatively associated with pod and grain damage by pod fly, might be because of oviposition non-preference by $M$. obtusa on the thick pod wall genotypes. Similar results have also been reported by Sithanantham et al. (1981). Trichomes have earlier been reported as one of the insect resistance traits by limiting the insect's contact with the plant or acting as a physical barrier in its movement by producing toxic compounds, which poison the insect through contact, ingestion, and/or inhalation, and by producing gummy, sticky or polymerizing chemical exudates, which impede the insect movement (Levin 1973; Duffey 1986; David and Easwaramoorthy 1988). The fluidity and volume of the exudates, whether toxic or sticky, varies with weather, time of day, crop species, and plant age (Koundal and Sinha 1981; Rembold et al. 1990). Glandular exudates from the trichomes of chickpea and pigeonpea play an important role in host plant resistance to pod borer, Helicoverpa armigera (Hubner) larvae (Yoshida et al. 1995; Green et al. 2002a, b). Present studies suggest that the pod fly resistant genotypes have more number of glandular and non-glandular trichomes, and the trichome density has significant and negative association with pod fly infestation ( $r=(0.85$ to $(0.90)$. Increase in trichome density on pigeonpea pods have also been reported to reduce oviposition and infestation by pod feeders in earlier studies (Sithanantham et al. 1981; Shanower et al. 1997).

Plants are known to produce certain chemical compounds, in different quantities and proportions, which affect the behavior of phytophagous insects in various ways (Schoonhoven 1968). These chemical compounds determine the feeding and food selection by the herbivores. Differences in pod chemistry have been reported to affect the preference of $H$. armigera larvae in pigeonpea (Green et al. 2002a). Crude extracts from pods of wild species of cowpea have been found to have antibiotic effects on pod bug, Clavigralla tomentosicollis Stal. (Koona et al. 2003). The reducing and non-reducing sugars have negative association with melon fruit fly, Bactrocera cucurbitae (Coquillett) infestation and larval density in bitter gourd (Dhillon et al. 2005). Similarly, the tannins in legume seeds decrease the activity of digestive enzymes and availability of proteins, amino acids, and mineral uptake by insects (Salunkhe et al. 1982), and relative concentrations of various phenols play an important role in determining the suitability of pigeonpea plant tissues to insects as food (Annadurai et al. 1990). The pod wall biochemical traits have earlier been reported to play an important role in pigeonpea for resistance to insects (Sithanantham et al. 1983; Dass and Odak 1987; Sahoo and Patnaik 2003). Present studies suggested that the pigeonpea pod walls with low protein, and high sugars, total phenols, tannins and crude fiber content, and high trichome density and more pod wall thickness suffered less pod fly, M. obtusa damage in pods and grains of pigeonpea, and can be attributed to the feeding non-preference by the larvae, and oviposition non-preference of the pod fly adults. Therefore, these physico-chemical pod traits can be used as marker traits to identify pigeonpea genotypes with diverse mechanisms of resistance to pod fly, and use in insect resistant breeding program.

\section{References}

A.O.A.C (1995) Official methods of analysis, 15th edn. Association of Analytical Chemists, Washington, DC, USA

Annadurai RS, Murugesan S, Senrayan R (1990) Age correlated tissue preference of Heliothis armigera (Hubner) and Spodoptera litura (F.) with special reference to phenolic substrates. Proc Indian Acad Sci (Animal Sci) 99:317-325 
Bhosale DJ, Nawale RN (1985) Field screening of pigeonpea germplasm against pod fly Melangromyza obtusa (Malloch). Indian J Entomol 47:92-97

Burns RE (1971) Methods for estimation of tannins in grain sorghum. Agron J 63:511-512

Dass SB, Odak SC (1987) Biochemical basis of resistance in pigeonpea pod walls to pod fly, Melanagromyza obtusa Malloch (Diptera: Agromyzidae). Crop Improv 14(1):64-68

David H, Easwaramoorthy S (1988) Physical resistance mechanisms in insect plant interactions. In: Ananthkrishnan TN, Raman A (eds) Dyanamics of insect-plant interactions: recent advances and future trends. Oxford and IBH Publishing, New Delhi, India, pp 45-70

De Ponti OMB (1977) Resistance in Cucumis sativus L. to Tetranychus urticae Koch. I. The role of plant breeding in integrated control. Euphytica 26:633

Dhillon MK, Naresh JS, Singh R, Sharma NK (2005) Influence of physico-chemical traits of bitter gourd, Momordica charantia $\mathrm{L}$. on larval density and resistance to melon fruit fly, Bactrocera cucurbitae (Coquillett). J Appl Entomol 129:393-399

Dubois M, Gilles KA, Hamilton JK, Rebers PA, Smith F (1956) Colorimetric method for determination of sugars and related substance. Anal Chem 28:350-356

Duffey SS (1986) Plant glandular trichomes: their partial role in defense against insects. In: Juniper BE, Southwood TRE (eds) Insects and the plant surface. Edward Arnold Publishers, London, UK, pp 151-172

Green PWC, Stevenson PC, Simmonds MSJ, Sharma HC (2002a) Can larvae of the pod borer, Helicoverpa armigera (Lepidoptera: Noctuidae), select between wild and cultivated pigeonpea [Cajanus sp. (Fabaceae)]? Bull Entomol Res 92:45-51

Green PWC, Stevenson PC, Simmonds MSJ, Sharma HC (2002b) Phenolic compounds on the pod surface of pigeonpea, Cajanus cajan, mediate feeding behaviour of larvae of Helicoverpa armigera. J Chem Ecol 29:811-821

Gupta SC, Lateef SS, Ariyanayagam RP (1991) Are determinates inferior to indeterminates in short-duration pigeonpea? Int Pigeonpea News1 13:11-13

ICRISAT (1992) The medium term plan, vol 1. International Crops Research Institute for the Semi-Arid Tropics, Patancheru 502 324, Andhra Pradesh, India, p 80

ICRISAT (1983) Pulse entomology (Pigeonpea) report of work, June 1983 to May 1984. Departmental Progress Report No. 9., International Crops Research Institute for the SemiArid Tropics, Patancheru 502 324, Andhra Pradesh, India

Koona P, Osisanya EO, Lajide L, Jackai LEN, Tamo M (2003) Assessment of chemical resistance of wild and cultivated Vigna species to the brown pod bug, Clavigralla tomentosicollis Stal. (Hem., Coeridae). J Appl Entomol 127:293298

Koundal KK, Sinha SK (1981) Mallic acid exudation and photosynthetic characteristics in Cicer arietinum. Phytochemistry 20:1251-1252

Lal SS, Yadava CP, Chandra S (1986) Suppression of pod fly damage through varietal selection. Int Pigeonpea Newsl 5:42-43

Lal SS, Yadava CP, Sachan JN (1988) Studies on some aspects of oviposition and damage of pod fly in relation to the host phenology. Indian J Pulses Res 1:83-88
Lateef SS, Pimbert MP (1990) The search for post plant resistance to Helicoverpa armigera in chickpea and pigeonpea at ICRISAT. In: Summary Proceedings of the first consultative group meeting on host selection behavior of Heliothis armigera. International Crops Research Institute for the Semi-Arid Tropics, Patancheru 502 324, Andhra Pradesh, India, pp 25-28

Levin DA (1973) The role of plant trichomes in plant defense. Q Rev Biol 48:3-15

Nene YL, Sheila VK (1990) Pigeonpea: geography and Importance. In: Nene YL, Hall SD, Sheila VK (eds) The Pigeonpea. Commonwealth Agricultural Bureau International, Wallingford, UK, pp 1-11

Reed W, Lateef SS (1990) Pigeonpea: pest management. In: Nines YL, Hall SD, Sheila VK (eds) The Pigeonpea. Commonwealth Agricultural Bureau International, Wallingford, UK, pp 349-374

Rembold H, Wallner P, Kohne A, Lateef SS, Grune M, Weigner C (1990) Mechanisms of host-plant resistance with special emphasis on biochemical factors. In: Chickpea in the Nineties: proceedings of the 2nd international workshop on chickpea improvement, December 1989. International Crops Research Institute for the Semi-Arid Tropics, Patancheru 502 324, Andhra Pradesh, India, pp 191-194

Sahoo BK, Patnaik HP (2003) Effect of biochemicals on the incidence of pigeonpea pod borers. Indian $\mathrm{J}$ Pl Prot 31(1):105-108

Salunkhe DK, Jadhav SJ, Kalam SS, Chavan JK (1982) Chemical, biochemical and biological significance of polyphenols in cereals legumes. CRC Rev Food Sci Tech 17:277-305

Schoonhoven LK (1968) Chemosensory basis of host plant selection. Annu Rev Entomol 13:115-136

Shanower TG, Romeis J, Minja EM (1999) Insect pests of pigeonpea and their management. Annu Rev Entomol 44:7796

Shanower TG, Yoshida M, Peter AG (1997) Survival, growth, fecundity and behavior of Helicoverpa armigera (Lepidoptera; Noctuidae) on pigeonpea (Cajanus cajan (L.) Millsp.) and two wild Cajanus species. J Econ Entomol 90:837841

Shanower TG, Lal SS, Bhagwat VR (1998) Biology and management of Melanagromyza obtusa (Malloch) (Diptera: Agromyzidae). Crop Prot 17(3):249-263

Sharma HC, Pampapathy G, Reddy LJ (2003) Wild relatives of pigeonpea as a source of resistance to the pod fly (Melanagromyza obtusa Malloch) and pod wasp (Tanaostigmodes cajaninae La Salle). Genet Resour Crop Evol 50:817-824

Singh HK, Singh HN (1990) Screening of certain pigeonpea cultivars sown at Kharif and Rabi crops against tur pod bug, Clavigralla gibbosa and pod fly, Melanagromyza obtusa. Indian J Entomol 52:320-327

Sithanantham S, Lateef SS, Reed W (1981) Pod fly susceptibility in pigeonpea: some aspects of oviposition preference. In: Proceedings of the international workshop on Pigeonpea, 15-19 December 1980, vol 2. International Crops Research Institute for the Semi-Arid Tropics, Patancheru 502 324, Andhra Pradesh, India, pp 329-335

Sithanantham S, Singh V, Reed W, Jambunathan R (1983) Differences of some chemical constituents of pigeonpea pod walls in relation to pod fly susceptibility. Int Pigeonpea News1 2:68-69 
Snell FD, Snell CT (1954) Colorimetric methods of analysis, vol 3. Van Nostrand Reinhold Company, New York, pp 232 and 461

Srivastava OS (1972) Estimation of loss in T 21 variety of arhar (Cajanus cajan L.) due to 'tur' pod fly (Melanagromyza obtusa Malloch). Indian J Entomol 34(1):82-83

Swain T, Hills WE (1959) The phenolic constituents of Prunus domestica 1 . The quantitative analysis of phenolic constituents. J Sci Food Agric 10:63-68

Thakur BS, Rawat RR, Verma R, Mottra A (1989) Influence of shape and size of pods of Cajanus cajan (L.) Millsp. on the susceptibility of pod fly, Melanagromyza obtusa (Malloch) pod bug, Clavigralla gibbosa Spinola. Indian J Entomol 51:159-162

Veda OP, Purohit ML, Sood NK (1975) Varietal susceptibility of 'arhar' Cajanus cajan (L.) Millsp. to Melanagromyza obtusa Mall., Exalastis atomosa Wlsm and Heliothis armigera $\mathrm{Hb}$. JNKVV Res J 9(1/2):7-9

Yoshida M, Cowgill SE, Weightman JA (1995) Mechanisms of resistance to Helicoverpa armigera (Lepidoptera: Noctuidae) in chickpea - role of oxalic acid in leaf exudates as an antibiotic factor. J Econ Entomol 88:1783-1786 